\title{
Survival and Productivity of Culinary Herb Species in a Nutrient Film Technique-type Aquaponic System with Nile Tilapia
}

\author{
Carlos Valdez-Sandoval ${ }^{1}$, Dennis Guerra-Centeno ${ }^{1}$, Manuel Lepe-López ${ }^{1}$, Mercedes Díaz-Rodríguez ${ }^{1}$ and Lariza \\ Pineda-Alvizuris ${ }^{2}$ \\ ${ }^{I}$ Instituto de Investigación en Ciencia Animal y Ecosalud, Facultad de Medicina Veterinaria y Zootecnia (FMVZ), Universidad de San Carlos de \\ Guatemala (USAC), Ciudad Universitaria zona 12, 01012, Guatemala City, Guatemala. \\ ${ }^{2}$ Escuela de Estudios de Postgrado, FMVZ, USAC, Ciudad Universitaria zona 12, 01012, Guatemala City, Guatemala. \\ *Corresponding author's Email: zoovaldez@gmail.com; (DORCiD: 0000-0002-8742-1320
}

\begin{abstract}
Aquaponics is an evolving technology for producing plants and fish (or other aquatic organisms) in an integrated water recirculating system. However, the survival and productivity of terrestrial plants in aquaponic systems have not been evaluated for most plant species. The present study aimed to analyze the survival rate, growth, and biomass production of eight culinary herbs, commonly used in Guatemala, in a Nutrient Film Technique-type (NFT) aquaponic system with Nile tilapia (Oreochromis niloticus). The investigated herbs included coriander (Coriandrum sativum), parsley (Petroselinum crispum), peppermint (Mentha spicata), thyme (Thymus vulgaris), samat (Eryngium foetidum), oregano (Plectranthus amboinicus), dill (Anethum graveolens), and basil (Ocimum basilicum). A total of 50 individuals of each herb species and 150 juvenile Nile tilapias were distributed in 5 aquaponic modules. The survival rate, growth, and biomass production were measured for herbs and tilapias. All the herb species survived against the NFT aquaponic conditions. The findings indicated that the herb survival was species-dependent and ranged $42-98 \%$. There was a significant effect of the herb species both on height and biomass gains. Post hoc comparison showed interspecific differential abilities to grow biomass in NFT aquaponics conditions. Among the investigated herbs, $M$. spicata and $O$. basilicum were the most productive species. Refinement in the selection of initial plants and aquaponic management could improve plant performance.
\end{abstract}

Keywords: Ecological production, Hydroponics, Oreochromis, Recirculating water, Sustainable aquaculture

\section{INTRODUCTION}

Aquaponics is an evolving technique to tackle climate change challenges in the agriculture industry (Tyson et al., 2011; König et al., 2018; Palm et al., 2018). In contrast to traditional agricultural resource management, an aquaponic system saves water and reduces waste, costs, and environmental contamination (Lennard and Leonard, 2006; Rizal et al., 2018). The reutilization of water and the use of waste from aquatic organisms to feed the plants in a closed system makes aquaponics a social, ecological, and healthier alternative to meet the sustainable development goals proposed by United Nations (United Nations, 2015; Li et al., 2018; Rizal et al., 2018). Regardless of the fact that aquaponics has been criticized by organic farmers for the industrial origin of the substrate and the absence of soil (Kledal et al., 2019), this form of producing has also been considered the agriculture of the future (Shafeena, 2016).

Although aquaponics has demonstrated to be effective and efficient for small and large scale productions of lettuce, tomatoes, and other salad greens (Somerville et al., 2014; Love et al., 2015), it seems that it is not possible for all plant species to survive and grow in aquatic conditions (Guerra-Centeno et al., 2016). Therefore, it is necessary to identify plant species that can be grown and produced in aquaponic conditions.

Guatemala is a megadiverse country, where many plant species are traditionally used for feeding, spicing, medicinal, and other cultural purposes (Cáceres, 1996; Villar-Anleu, 1998; Knapp and Davidse, 2006). However, there is a dearth of research addressing the productivity of Guatemalan plant species in aquaponic conditions (Guerra-Centeno et al., 2016). Since biomass production is a function of survival and growth, the aim of the current study was to examine these features in eight culinary herb species mainly used in Guatemala (coriander [Coriandrum sativum L.], parsley [Petroselinum crispum (Mill.) Fuss], peppermint [Mentha spicata L.], thyme [Thymus vulgaris, L.], samat [Eryngium foetidum, L.], oregano [Plectranthus amboinicus (Lour.) Spreng], dill [Anethum graveolens L.] and basil [Ocimum basilicum L.]) using a Nutrient Film Technique-type (NFT) aquaponic system with Nile tilapia (Oreochromis niloticus L.). 


\section{MATERIALS AND METHODS}

\section{Ethical approval}

This study was reviewed and approved by the Graduate School Bioethics Committee of the Faculty of Veterinary Medicine and Animal Husbandry of the University of San Carlos of Guatemala, Guatemala City.

\section{Study site}

The study was performed inside a greenhouse, in the facilities of the Instituto de Investigación en Ciencia Animal y Ecosalud (IICAE) at the Veterinary and Animal Husbandry Faculty, University of San Carlos of Guatemala, located in Guatemala City.

\section{Study design}

The samples in the current study consisted of eight herb species. Depending on the herb species, seedlings or cuttings were used as propagules (Table 1). The performance of each sample was examined using aquaponic modules (Figure 1). Each module had 8 perforated pipelines and each pipeline had 10 holes. Each pipeline was considered as a block and only housed individuals of a single herb species. Therefore, each aquaponic module held 80 plant individuals (10 per species). This arrangement was replicated in five aquaponic modules. The observation period in aquaponic conditions lasted 90 days, from June to August 2018.

\section{Aquaponic system and modules}

The aquaponic modules at the IICAE consisted of a water tank, a pump, a biofilter, and a pipeline circuit. For each module, one plastic $750 \mathrm{~L}$ water tank was used. For pumping the water, one submersible 0.5 horsepower pump (BOS Truper ${ }^{\circledR}$, Mexico) was installed and a hose was coupled to conduct the water flow from the tank to a biofilter (Clear Choice PF-1, Tetra ${ }^{\circledR}$, Blacksburg, VA, USA). Two 4' PVC pipeline circuits were installed in a zigzag arrangement (Figure 1). Water flow was regulated using a nutrient film technique-type (NFT) design.

\section{Herb management}

The herb materials were obtained from commercial suppliers (Superb Superseed S.A and Vivero Botanik, Guatemala City). Prior to the observation period in aquaponic conditions, coriander, parsley, samat, dill, and basil seeds as well as peppermint, thyme, and oregano cuttings were placed into seedbeds with fertilized soil where they remained for up to eight weeks. The herbs were then transplanted to the NFT modules. Only the propagules that had three to five leaflets were selected to be transplanted to the aquaponic conditions.

\section{Tilapia management}

While the plant material was in the seedbeds, 300 juvenile Nile tilapia, weighing about $1.5 \mathrm{~g}$ each, were obtained from a commercial farm (Cazali Tilapia Farm, Escuintla, Guatemala) and put under quarantine for 30 days in a plastic $1000 \mathrm{~L}$ water tank. After that period, 30 tilapia organisms, weighing 2-4 g each, were selected and placed in the water tank of each NFT module (i.e., a total of 150 fish) to start the aquaponic phase. All tilapia organisms were managed following the Food and Agriculture Organization recommendations for small-scale aquaponic food production (Somerville et al., 2014). During the first 30 days of the study, tilapias were fed $45 \%$ protein extruded food (Tilapia ${ }^{\text {TM }}$, Alcon, Honduras), and from day 31 to day 90, tilapias were fed $32 \%$ protein extruded food (Tilapia ${ }^{\mathrm{TM}}$, Alcon, Honduras).

\section{Measurements}

The height/length and weight of each herb and tilapia organism were measured and recorded at days 0,45 , and 90 of the aquaponic observation period. The height of the plants was measured from the base of the stem to the tip of the apical meristem whilst the length of the tilapia organisms was measured from the tip of the snout, with mouth closed, to the extreme of the tail fin. Heights and lengths were measured in centimeters using a measuring tape and approximated to the nearest tenth. The weight was measured in grams using an electronic balance (iBalance $700^{\mathrm{TM}}$, My Weigh, AZ, USA) and approximated to the nearest tenth. Differences between initial and final measurements were recorded. Growth was considered as both height/length and weight (biomass) gains. The values related to water temperature, $\mathrm{pH}$, electric conductivity, and total dissolved solids were measured every 15 days using a digital tester (HI 991300 TM, Hanna, RI, USA) and the mean values were calculated.

\section{Statistical analyses}

The descriptive statistics included the calculation of the mean and standard deviations for height/length and weight measurements of herbs and tilapia. Since the obtained data did not meet the assumptions of normality, the non- 
parametric test of Kruskal-Wallis was used to compare the means values of plant longitudinal growth and biomass production. In this regard, the post hoc test of Mann-Whitney pairwise was run to determine the specific differences. The correlation between survival rate and herb species was analyzed using the Pearson's chi-squared test. Statistical analyses were performed using Past Program ${ }^{\circledR}$, version 3.20 (Hammer et al., 2001). The significance level for the statistical tests was $\mathrm{p}<0.05$.

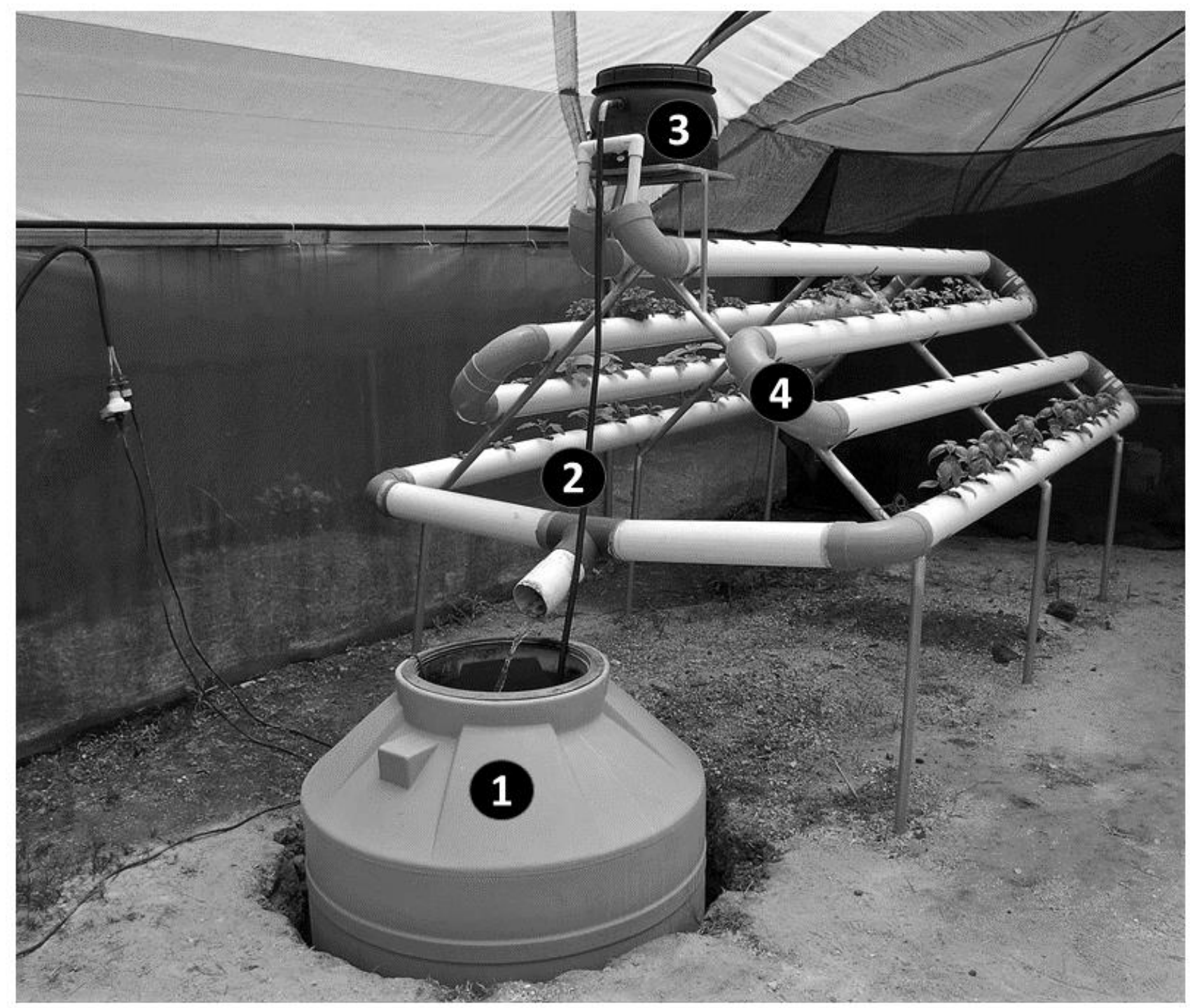

Figure 1. Components of a nutrient film technique (NFT) aquaponic module at the IICAE greenhouse, including (1) water container with a submersible pump; (2) hose to conduct the water from the tank to the biofilter; (3) biofilter; (4) PVC pipe circuits for water circulation and plant hosting.

Table 1. Descriptive statistics of experimental arrays of eight investigated herbs species in five aquaponics modules

\begin{tabular}{lccc}
\hline Herb species & $\begin{array}{c}\text { Number of individuals per } \\
\text { pipeline, per module }\end{array}$ & $\begin{array}{c}\text { Total number of } \\
\text { individuals }\end{array}$ & $\begin{array}{c}\text { Type of } \\
\text { propagule }\end{array}$ \\
\hline Coriander (Coriandrum sativum) & 10 & 50 & Seedling \\
Parsley (Petroselinum crispum) & 10 & 50 & Seedling \\
Peppermint (Mentha spicata) & 10 & 50 & Cutting \\
Thyme (Thymus vulgaris) & 10 & 50 & Cutting \\
Samat (Eryngium foetidum) & 10 & 50 & Seedling \\
Oregano (Plectranthus amboinicus) & 10 & 50 & Cutting \\
Dill (Anethum graveolens) & 10 & 50 & Seedling \\
Basil (Ocimum basilicum) & 10 & 50 & Seedling \\
\hline Total & 80 & 400 & -- \\
\hline
\end{tabular}


The findings of the current study indicated that all herb species survived to the NFT aquaponic conditions. Survival rates were within the range of 0.42-0.98 (Table 2) and were associated with herb species $(\mathrm{p}<0.01)$. There was a significant effect of the herb species both on height $(\mathrm{p}<0.01)$ and biomass $(\mathrm{p}<0.01)$ gains. The obtained results of post hoc comparison were indicative of interspecific differential abilities to grow biomass in NFT aquaponics conditions (Table 3). Peppermint and basil were the most productive species. Regarding biomass production, the growth rate of plants varies according to their species (Figures 2 and 3). For most plant species, growth was marked by a slow initial phase, followed by an accelerated phase (Figure 4).

\section{Survival and productive parameters of Tilapia}

Tilapias survived and showed a growing response in the water tanks of the NFT aquaponic modules (Table 4).

\section{Water parameters}

The mean values related to water temperature, $\mathrm{pH}$, electric conductivity, and total dissolved solids were $24.9 \pm 1.2$ ${ }^{\circ} \mathrm{C}, 7.8 \pm 0.5,458.1 \pm 309.7 \mu \mathrm{S}, 232.7 \pm 157.4$ ppm, respectively.

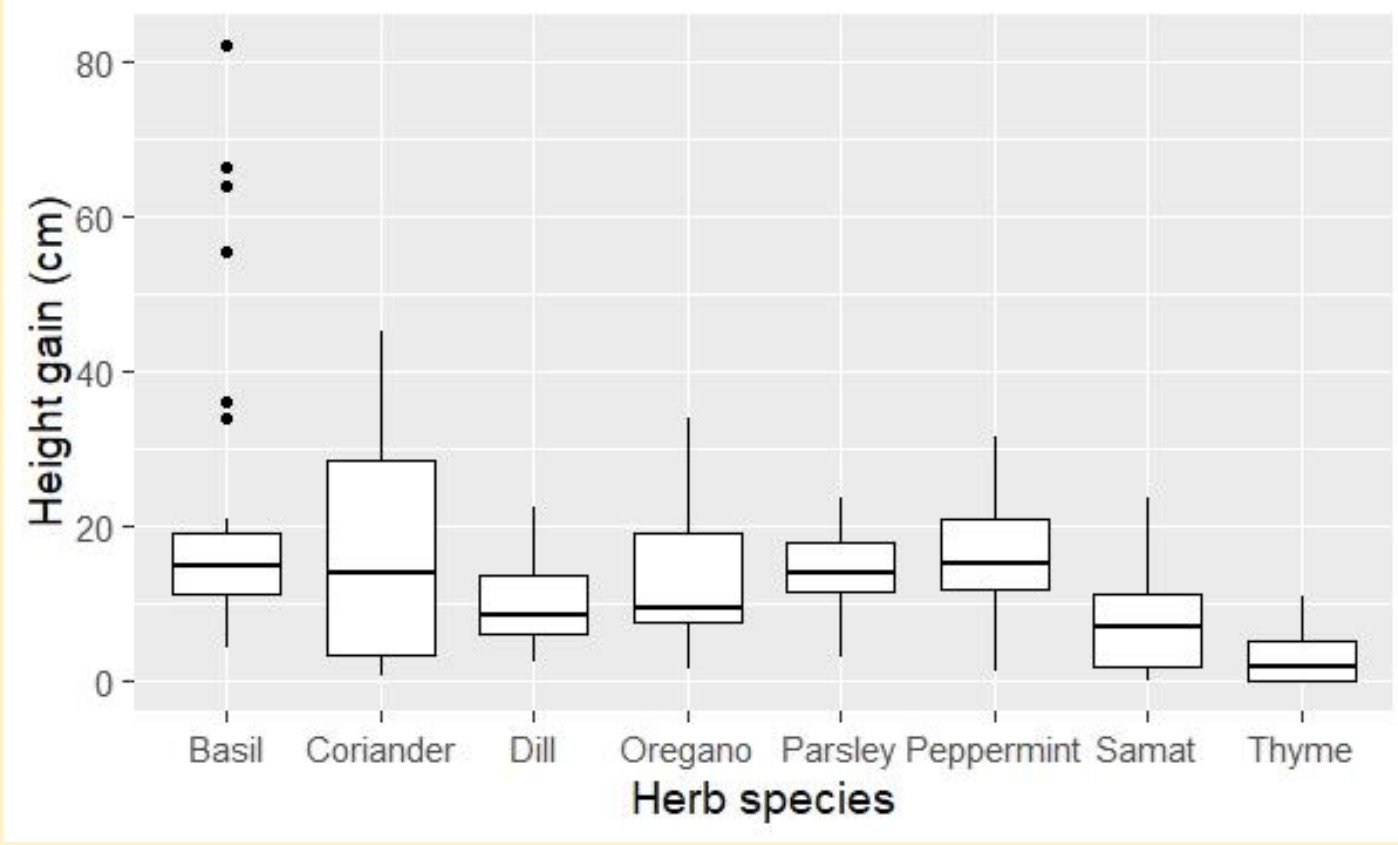

(a)

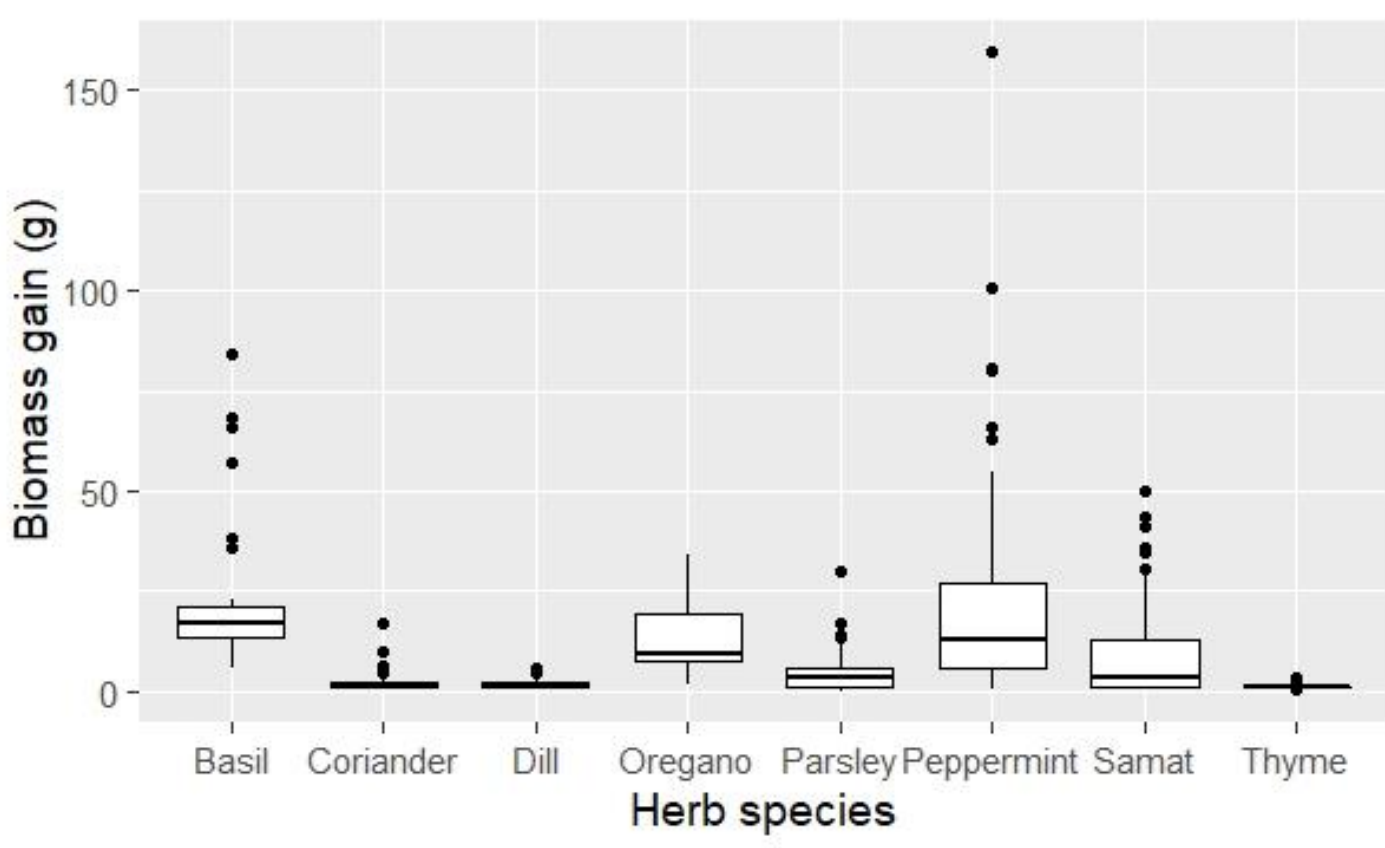

(b)

Figure 2. Variation in biomass production for survivors of eight herb species in NFT aquaponic conditions, by day 90 of observation: $a=$ height gain; $b=$ biomass gain. 


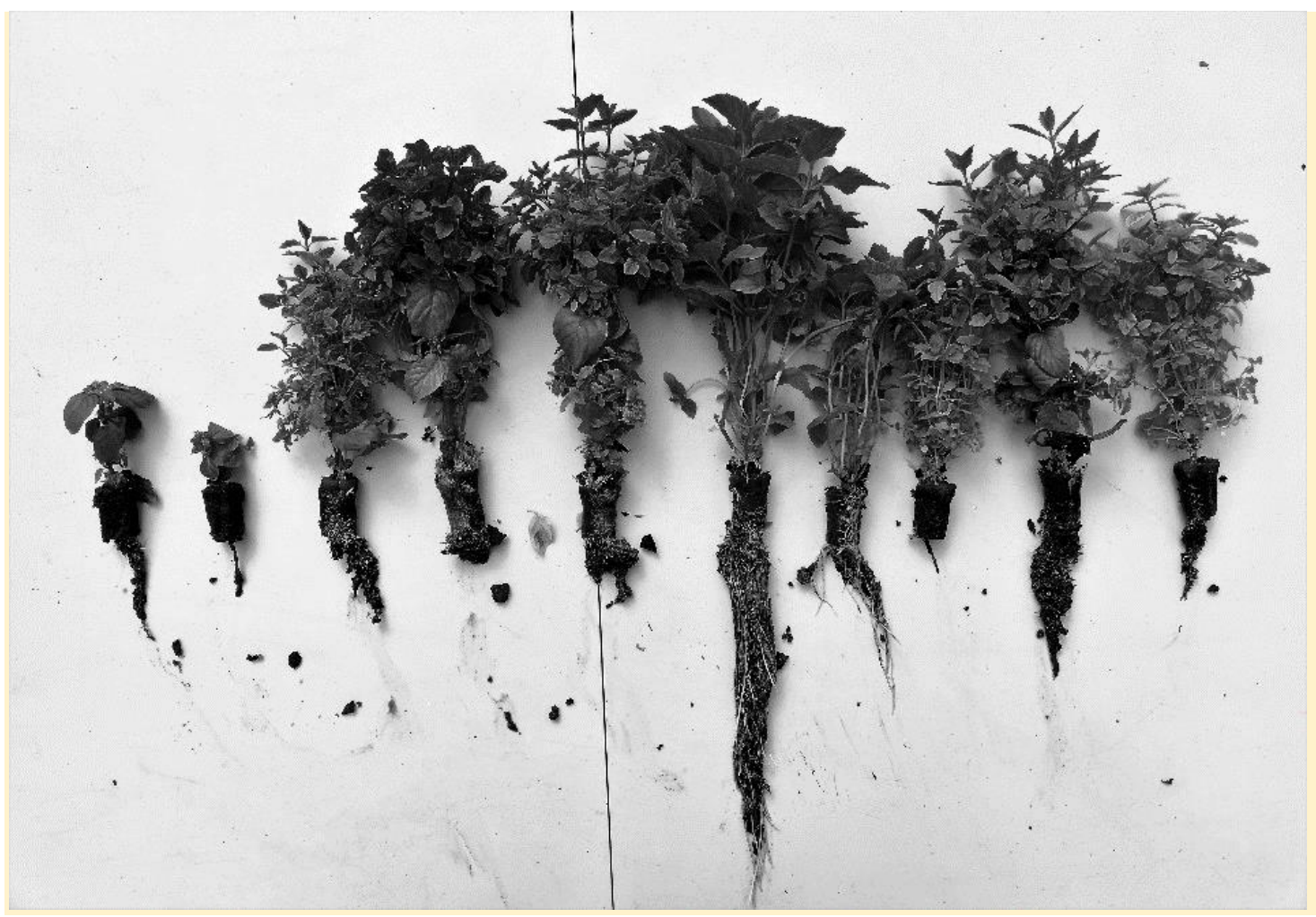

Figure 3. Variation in growth of peppermint individuals from the same block, by day 90 of observation period.

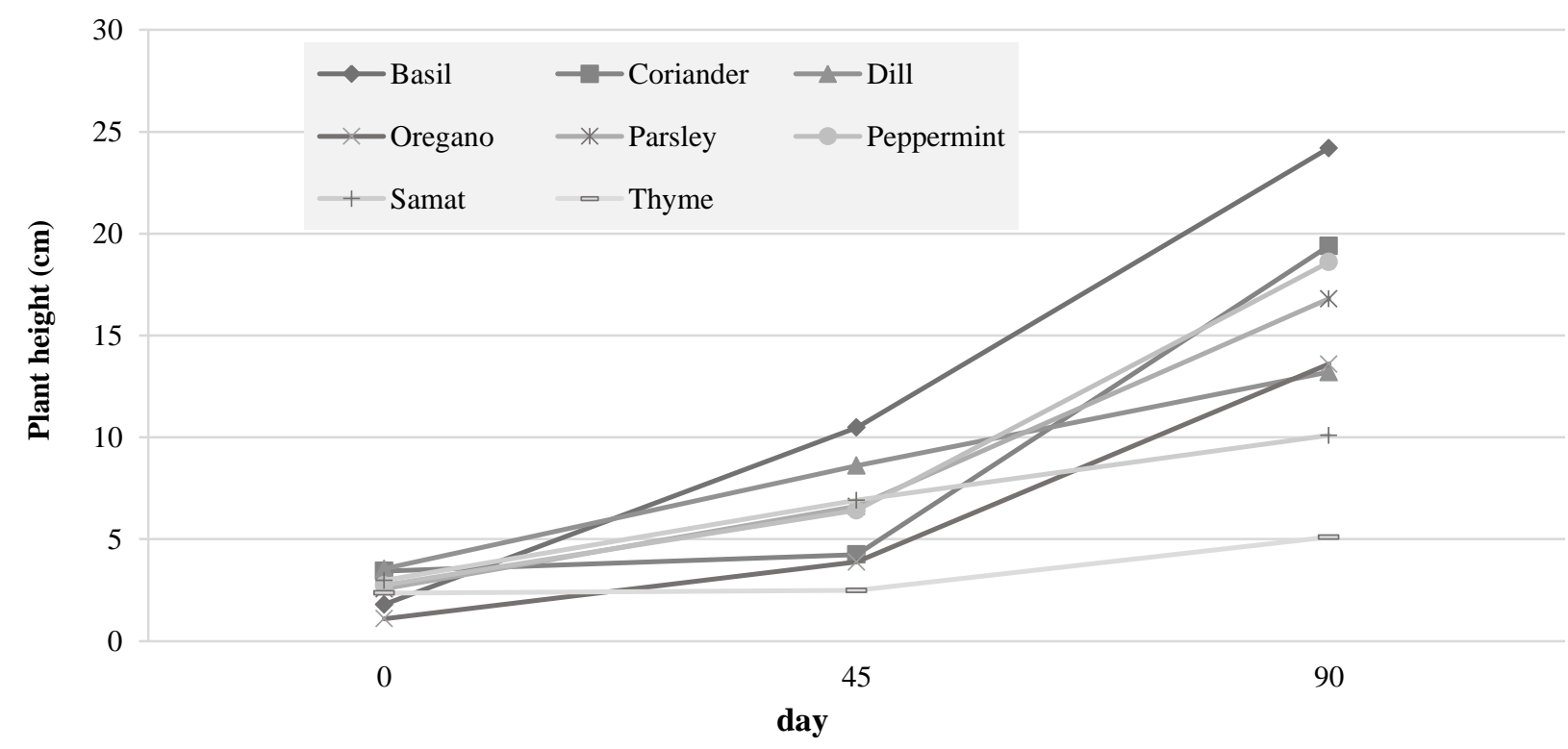

Figure 4. Mean height for eight species of culinary herbs in an NFT aquaponic system from transplantation (day 0) to the end of the observation period (day 90).

Table 2. Survival rate and biomass production of eight herb species in an NFT aquaponic system after 90 days of observation

\begin{tabular}{lcccc}
\hline Herb species & $\begin{array}{c}\text { Final number } \\
\text { (survival rate) }\end{array}$ & $\begin{array}{c}\text { Height gain } \\
\text { median (range) [cm] }\end{array}$ & $\begin{array}{c}\text { Biomass gain } \\
\text { median (range) [g] }\end{array}$ & $\begin{array}{c}\text { Total biomass per species at } \\
\text { day 90 (g) }\end{array}$ \\
\hline Coriander & $19(0.38)$ & $16.0(4.0-47.0)$ & $1.7(0.5-16.7)$ & 69.2 \\
Parsley & $49(0.98)$ & $17.0(5.0-25.0)$ & $3.3(0.0-29.9)$ & 242.8 \\
Peppermint & $49(0.98)$ & $17.0(4.0-34.0)$ & $12.7(0.5-159.5)$ & 1168.9 \\
Thyme & $38(0.76)$ & $4.5(1.0-13.0)$ & $0.9(0.5-3.5)$ & 48.7 \\
Samat & $44(0.88)$ & $9.0(1.0-25.0)$ & $3.1(0.2-49.8)$ & 418.4 \\
Oregano & $21(0.42)$ & $10.0(2.0-35.0)$ & $9.2(1.4-33.8)$ & 265.4 \\
Dill & $29(0.58)$ & $12.0(2.0-25.0)$ & $1.1(0.5-5.9)$ & 54.9 \\
Basil & $27(0.54)$ & $17.0(6.0-84.0)$ & $16.7(5.9-83.9)$ & 1006.5 \\
\hline The initial number of individuals was 50 for all species. NFT: nutrient film technique & &
\end{tabular}


Table 3. Mann Whitney Pairwise post hoc comparisons for biomass gain values of eight herb species

\begin{tabular}{|c|c|c|c|c|c|c|c|c|}
\hline Items & Coriander & Parsley & Peppermint & Thyme & Samat & Oregano & Dill & Basil \\
\hline Coriander & - & .011 & $<.001$ & .084 & .037 & $<.001$ & .728 & $<.001$ \\
\hline Parsley & .011 & - & $<.001$ & $<.001$ & .991 & $<.001$ & .001 & $<.001$ \\
\hline Peppermint & $<.001$ & $<.001$ & - & $<.001$ & $<.001$ & .356 & $<.001$ & .129 \\
\hline Thyme & .084 & $<.001$ & $<.001$ & - & .002 & $<.001$ & .027 & $<.001$ \\
\hline Samat & .037 & .991 & $<.001$ & .002 & - & .005 & .045 & $<.001$ \\
\hline Oregano & $<.001$ & $<.001$ & .356 & $<.001$ & .005 & - & $<.001$ & .007 \\
\hline Dill & .728 & .001 & $<.001$ & .027 & .045 & $<.001$ & - & $<.001$ \\
\hline Basil & $<.001$ & $<.001$ & .129 & $<.001$ & $<.001$ & .007 & $<.001$ & - \\
\hline
\end{tabular}

Table 4. Survival and production parameters of Nile tilapia in an NFT aquaponic system at day 90.

\begin{tabular}{lc}
\hline Parameters & Mean (SD) \\
\hline Mean final number per module & $27.0(1.9)$ \\
Mean survival rate per module (\%) & $90.0(6.2)$ \\
Mean final individual length (cm) & $17.3(2.2)$ \\
Mean final individual weight (g) & $106.2(37.9)$ \\
Mean biomass per tank (g) & $2866.2(660.9)$ \\
\hline
\end{tabular}

NFT: nutrient film technique; SD: standard deviation

\section{DISCUSSION}

All the evaluated species showed some potential to survive and grow in NFT aquaponics conditions. However, the observed variation in survival rate and biomass production suggested the existence of some factors affecting both individual and species-related abilities for production in aquaponic conditions. The outcomes of the current study underlined the more recent studies on the differential abilities of plant species in terms of biomass adaptation and production in NFT aquaponics (Hu et al., 2015; Guerra-Centeno et al., 2016; Valdez-Sandoval et al., 2017), according to which a large number of factors could contribute to such differences. To name a few, the findings of the present study suggested propagule size (in the early aquaponic stage), hydraulic charge (water flow), and root-covering algae as the most important growth-limiting factors. Life in aquatic conditions might be the most important constrain to earthevolved plant species. It is known that flooding hinders growth and development for most vascular plants (Jackson and Colmer, 2005). The major constrain in flooding conditions is an inadequate supply of oxygen to the submerged roots. Oxygen diffusion in water is about 10,000 times slower than in air (Colmer, 2003). Some flood-resistant plant species can survive and even grow in flooding conditions due to various evolutive adaptations, including metabolic, hormonal, and morphological responses (e.g., adventitious roots and aerenchyma, Blom and Voesenek, 1996; Visser et al., 2000, Visser et al., 2003). As a result, it can be concluded that although it is impossible for all the plant species to survive in floodplains, some plant species could survive in aquaponic conditions if oxygen is available to plant roots via circulating water (Maucieri et al., 2018).

Regardless of water recirculation and oxygen carriage in aquaponic NFT systems, a hemp wick is required in case of small transplanted propagules to pass water from the nutrient film flow to the plant substrate by capillarity. This issue usually causes water stagnation in the substrate inside the net pots that can, to some extent, decreased oxygen availability for the plant. In the present study, there were instances of water stagnation, death or poor foliage, and root development in some coriander, parsley, thyme, oregano, and dill individuals which neither survived nor showed growth.

Bigger propagules with well-developed roots, such as those of beans and peppers, can easily reach the water flow and survive the water stasis inside the plant substrate (Valdez-Sandoval et al., 2017). Leaves and stems development could favor survival in early aquaponic stages as atmospheric oxygen can be captured via stomas and lenticels through convection (Pardos, 2004). Other aquaponic systems, such as a raft or floating bed, could favor the survival and growth of little propagules, as the tiny roots (i.e., typical of early propagules) directly contact the recirculating water. However, it should be mentioned that a larger amount of water may lead to a lower density of nutrients and less absorption by the propagules (Lennard and Leonard, 2006).

Another issue of consideration in the current study was related to the association between algae and suspended solids accumulation in the roots and delayed plant growth. The algae or solids film that forms on the root system could 
block the diffusion of oxygen and other nutrients from the water film to the roots (Roosta and Afsharipoor, 2012; Hu et al., 2015). However, this possible growth-inhibition factor must be examined more thoroughly in experimental conditions.

A third factor that could decrease survival and growth is the speed of the water flow. It is known that high hydraulic loads cut the contact time between roots and water, and consequently hinder the absorption of nutrients (Wongkiew et al., 2017). Additionally, the mechanical action of the water flow that permanently impacts the root system of the plant can affect the formation of adventitious roots, an important factor for radicular aerenchyma formation (Blom and Voesenek, 1996). The low growth of many thyme individuals (i.e., the size remained almost the same as transplantation size) in the present study could be due to the effect of such mechanical action. However, the obtained results of such low growth may vary according to the plant species and, therefore, this issue should be empirically investigated for all plant species.

Concerning the growing behavior of plants, the generalized slow growth rate observed in the first days is consistent with our earlier observations (Guerra-Centeno et al., 2016; Valdez-Sandoval et al., 2017). This slow growth rate was probably caused by a low nitrogenated waste production when the fish were still small. Once the fish get larger in size, the amount of available nitrogenous waste allows the accelerated growth of the plants, depending on their species (Hu et al., 2015). Additionally, many of the herb individuals exhibited a retarded radicular development during some weeks after transplantation to the NFT modules. Based on the findings of the current study, it can be concluded that the stagnant phase that eventually retarded growth and biomass production could be overcome using more mature propagules with well-developed roots. Direct contact of well-developed roots with the recirculating water not only favors oxygen absorption but also nitrogen uptake (Hu et al., 2015).

Another interesting finding of this study was the divergent ability of individual plants to survive, adapt, and grow in NFT aquaponic conditions. This can suggest that the genetic traits of the fittest individuals can be fixed through selection management leading to the technical and financial feasibility for small or large production. In the current study, peppermint and basil were the only herb species that showed small and large-scale production potential in the NFT system. However, the rest of the species should not be undervalued by these results.

With regard to tilapia, the observed survival rates and growth responses were higher or consistent with earlier studies in similar conditions (Mbahinzireki et al., 2001; Coyle et al., 2004; Bahnasawy, 2009). This confirms the feasibility of tilapia to produce in recirculating systems supporting their sustainability and economical profitability (Blidariu and Grozea, 2011).

In the present study, the plant performance values were, in general, below those reported for aquaponic (EspinosaMoya et al., 2018) or soil conditions (Telci et al., 2004; Salim et al., 2014); therefore, there is a need to do further studies in order to derive conclusions and decisive decisions in selecting the investigated herb species for production purposes in conditions similar to the IICAE NFT systems.

\section{CONCLUSION}

Peppermint (Mentha spicata) and basil (Ocimum basilicum) were the most productive species in NFT aquaponics conditions. Among the investigated species, the obtained results of these plants showed potential for commercial or domestic production. Based on the findings of the current study, it is, however, believed that the survival and production capabilities of the other herb species in NFT aquaponics conditions could be improved by refinement or modifications in the management techniques, including initial individual plant selection, water flow management, suspended solids management, and algae control.

\section{DECLARATIONS}

\section{Acknowledgments}

This research was co-financed with public funds administered by Dirección General de Investigación, University of San Carlos of Guatemala (budget line 4.8.63.2.59, year 2018).

\section{Competing interests}

The authors declared no conflict of interest.

\section{Authors' contribution}

Carlos Valdez-Sandoval designed the plan of the study and managed the funds. Dennis Guerra-Centeno conceived the idea and drafted the manuscript. Manuel Lepe-López analyzed and interpreted the data. Mercedes Díaz-Rodríguez collected the data and reviewed the manuscript. Lariza Pineda-Alvizures processed the data and reviewed the manuscript. 
Bahnasawy MH (2009). Effect of dietary protein levels on growth performance and body composition of monosex Nile tilapia, Oreochromis niloticus L. reared in fertilized tanks. Pakistan Journal of Nutrition, 8(5): 674-678. DOI: https://www.doi.org/10.3923/pjn.2009.674.678

Blidariu F and Grozea A (2011). Increasing the economical efficiency and sustainability of indoor fish farming by means of aquaponics-review. Scientific Papers Animal Science and Biotechnologies, 44(2):1-8. Available at: http://www.spasb.ro/index.php/spasb/article/view/287/168

Blom CWPM and Voesenek LACJ (1996). Flooding: the survival strategies of plants. Trends in Ecology \& Evolution, 11(7): 290-295. DOI: https://www.doi.org/10.1016/0169-5347(96)10034-3

Cáceres A (1996). Plantas de uso medicinal en Guatemala. Editorial Universitaria, Guatemala, pp. 401-402.

Colmer TD (2003). Long-distance transport of gases in plants: a perspective on internal aeration and radial oxygen loss from roots. Plant, Cell \& Environment, 26(1): 17-36. DOI: https://www.doi.org/10.1046/j.1365-3040.2003.00846.x

Coyle SD, Mengel GJ, Tidwell JH and Webster CD (2004). Evaluation of growth, feed utilization, and economics of hybrid tilapia, Oreochromis niloticus $\times$ Oreochromis aureus, fed diets containing different protein sources in combination with distillers dried grains with solubles. Aquaculture Research, 35(4): 365-370. DOI: https://www, doi.org/10.1111/j.1365-2109.2004.01023.x

Espinosa-Moya A, Alvarez-Gonzalez A, Albertos-Alpuche P, Guzman-Mendoza R and Martínez-Yáñez R (2018). Growth and development of herbaceous plants in aquaponic systems. Acta Universitaria, 28(2):1-8. DOI: https://www.doi.org/10.15174/au.2018.1387

Guerra-Centeno D, Valdez-Sandoval C, Aquino-Sagastume E, Díaz M and Ríos L (2016). Adaptación y rendimiento de plantas autóctonas de Guatemala en un sistema acuapónico. Revista Electrónica de Veterinaria, 17(11): 1-13. Available at: https://www.redalyc.org/pdf/636/63649051013.pdf

Hammer O, Harper DAT and Ryan PD (2001). PAST: Paleontological Statistics Software Package for Education and Data Analysis.

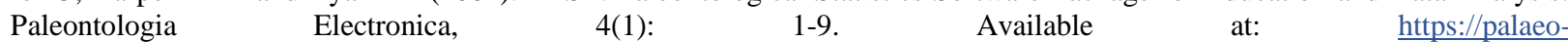
electronica.org/2001_1/past/issue1_01.htm\#: :text=The\%20program\%2C\%20called\%20PAST\%20(PAleontological,plotting\%2 C\%20and\%20simple\%20phylogenetic\%20analysis.

Hu Z, Lee JW, Chandran K, Kim S, Brotto AC and Khanal SK (2015). Effect of plant species on nitrogen recovery in aquaponics. Bioresource Technology, 188: 92-98. DOI: https://www.doi.org/10.1016/j.biortech.2015.01.013

Jackson MB and Colmer TD (2005). Response and adaptation by plants to flooding stress. Annals of Botany, 96(4): 501-505. DOI: https://www.doi.org/10.1093/aob/mci205

Kledal PR, König B and Matulić D (2019). Aquaponics: The Ugly Duckling in Organic Regulation. In Goddek S., Joyce A., Kotzen B., \& Burnell G. (Eds.), Aquaponics Food Production Systems, Springer, Cham, pp.487-500 (Ch). DOI: https://www.doi.org/10.1007/978-3-030-15943-6_19

Knapp S and Davidse G (2006). Flora of Guatemala. In E. Cano (Editor), Biodiversidad de Guatemala, Volume I. Universidad del Valle, Guatemala, pp. 24-47.

König B, Janker J, Reinhardt T, Villarroel M and Junge R (2018). Analysis of aquaponics as an emerging technological innovation system. Journal of Cleaner Production, 180: 232-243. DOI: https://www.doi.org/10.1016/j.jclepro.2018.01.037

Lennard WA and Leonard BV (2006). A comparison of three different hydroponic sub-systems (gravel bed, floating and nutrient film technique) in an aquaponic test system. Aquaculture International, 14(6): 539-550. DOI: http://www.dx.doi.org/10.1007/s10499006-9053-2

Li C, Lee CT, Gao Y, Hashim H, Zhang X, Wu WM and Zhang Z (2018). Prospect of aquaponics for the sustainable development of food production in urban. Chemical Engineering Transactions, 63: 475-480. DOI: https://www.doi.org/10.3303/CET1863080

Love DC, Fry JP, Li X, Hill ES, Genello L, Semmens K and Thompson RE (2015). Commercial aquaponics production and profitability: Findings from an international survey. Aquaculture, 435: 67-74. DOI: https://www.doi.org/10.1016/j.aquaculture.2014.09.023

Maucieri C, Nicoletto C, Junge R, Schmautz Z, Sambo P and Borin M (2018). Hydroponic systems and water management in aquaponics: A review. Italian Journal of Agronomy, 13(1): 1-33. DOI: https://www.doi.org/10.4081/ija.2017.1012

Mbahinzireki GB, Dabrowski K, Lee KJ, El-Saidy D and Wisner ER (2001). Growth, feed utilization and body composition of tilapia (Oreochromis sp.) fed cottonseed meal-based diets in a recirculating system. Aquaculture Nutrition, 7(3): 189-200. DOI: https://www.doi.org/10.1046/j.1365-2095.2001.00172.x

Palm HW, Knaus U, Appelbaum S, Goddek S, Strauch SM, Vermeulen T, Haïssam M and Kotzen B (2018). Towards commercial aquaponics: A review of systems, designs, scales and nomenclature. Aquaculture International, 26(3): 813-842. DOI: https://www.doi.org/10.1007/s10499-018-0249-z

Pardos JA (2004). Responses of plants to soil flooding. Forest Systems, 13(4): 101-107. DOI: https://doi.org/10.5424/srf/200413S1$\underline{00858}$

Rizal A, Dhahiyat Y, Andriani Y, Handaka AA and Sahidin A (2018). The economic and social benefits of an aquaponic system for the integrated production of fish and water plants. IOP Publishing, 137: 1-8. DOI: https://www.doi.org/10.1088/1755$\underline{1315 / 137 / 1 / 012098}$

Roosta HR and Afsharipoor S (2012). Effects of different cultivation media on vegetative growth, ecophysiological traits and nutrients concentration in strawberry under hydroponic and aquaponic cultivation systems. Advances in Environmental Biology, 6(2): 543-555. Available at: https://pdfs.semanticscholar.org/3103/f53bf4f771a4bf66b7b6889cdd981e678e80.pdf

Salim EA, El Hassan GM and Khalid HES (2014). Effect of spacing and seasonal variation on growth parameters, yield and oil content of mint plants. Journal of Forest Products \& Industries, 3: 71-74. DOI: https://www.doi.org/10.13140/RG.2.1.5166.3600 
Shafeena T (2016). Smart aquaponics system: challenges and opportunities. European Journal of Advances in Engineering and Technology, 3(2): 52-55. Available at: http://www.ejaet.com/PDF/3-2/EJAET-3-2-52-55.pdf

Somerville C, Cohen M, Pantanella E, Stankus A and Lovatelli A (2014). Small-scale aquaponic food production: integrated fish and plant farming. Food and Agriculture Organization of the United Nations, Rome, Italy 589: 281-288. Available at: http://www.fao.org/3/a-i4021e.pdf

Telci I, Sahbaz NI, Yilmaz G and Tugay ME (2004). Agronomical and chemical characterization of spearmint (Mentha spicata L.) originating in Turkey. Economic Botany, 58(4):721. DOI: https://www.doi.org/10.1663/00130001(2004)058[0721:AACCOS]2.0.CO;2

Tyson RV, Treadwell DD and Simonne EH (2011). Opportunities and challenges to sustainability in aquaponic systems. Hort Technology, 21(1): 6-13. DOI: https://www.doi.org/10.21273/HORTTECH.21.1.6

United Nations (2015). Transforming our world: The 2030 agenda for sustainable development. Resolution adopted by the General

$$
\text { New }
$$

York 70(1):1-35.

Available

https://www.un.org/en/development/desa/population/migration/generalassembly/docs/globalcompact/A RES $70 \quad 1$ E.pdf

Valdez-Sandoval C, Guerra-Centeno D, Díaz M and Ríos L (2017). Adaptación, crecimiento y rendimiento de variedades de chile nativos de Guatemala en un sistema acuapónico con tilapia nilótica. Revista Electrónica de Veterinaria, 18(5): 1-11. Available at: https://www.redalyc.org/pdf/636/63651419005.pdf

Villar-Anleu L (1998). La flora silvestre de Guatemala. Editorial Universitaria, Guatemala, pp. 1-63.

Visser EJW, Colmer TD, Blom CWPM and Voesenek LACJ (2000). Changes in growth, porosity, and radial oxygen loss from adventitious roots of selected mono-and dicotyledonous wetland species with contrasting types of aerenchyma. Plant, Cell \& Environment, 23(11): 1237-1245. DOI: https://www.doi.org/10.1046/j.1365-3040.2000.00628.X

Visser EJW, Voesenek LACJ, Vartapetian BB and Jackson MB (2003). Flooding and plant growth. Annals of Botany, 91(2): 107109. DOI: https://www.doi.org/10.1093/aob/mcg014

Wongkiew S, Hu Z, Chandran K, Lee JW and Khanal SK (2017). Nitrogen transformations in aquaponic systems: A review. Aquacultural Engineering, 76: 9-19. DOI: https://www.doi.org/10.1016/j.aquaeng.2017.01.004 